Rapp. Grønlands geol. Unders. 99, 129-135 (1980)

\title{
THE GEOCHEMISTRY OF STREAM SILT, NORTH GREENLAND
}

\author{
Agnete Steenfelt
}

As part of a reconnaissance drainage sampling programme directed towards mineral exploration (Ghisler et al., 1979; Henriksen, this report), 318 samples of stream silt, collected in 1978, have been analysed for 18 elements by radioisotope excited energy-dispersive $\mathrm{X}$-ray fluorescence and for $\mathrm{U}$ by delayed neutron counting. The results are used to describe the variation of element concentrations with respect to regional and lithostratigraphical changes in the Peary Land region. When these variations are known, anomalous concentrations of elements can be distinguished and their significance evaluated with respect to possible mineralisations.

\section{Geochemistry of lithostratigraphical units}

In dry arctic terrains the bedrock geochemistry is closely reflected by the chemistry of the sediment deposited in streams (Steenfelt \& Kunzendorf, 1979). The variation in the stream silt chemistry, illustrated by Table 10 and fig. 58, therefore reflects the lithogeochemical changes in the survey area.

The samples are sorted according to the chemical composition of the $<75 \mu \mathrm{m}$ grain size fraction. With emphasis on major element contents, four groups are established representing the main lithological units:

\begin{tabular}{llccll}
\hline & $\mathrm{K} \%$ & $\mathrm{Ca} \%$ & $\mathrm{Fe} \%$ & Trace elements \\
\hline I & Basic volcanic rocks & $<2.2$ & $1.5-4.5$ & $>4.0$ & high Ti, U, Mn, Cr; low RB, U \\
II & Sandstone & $1.4-6.2$ & $<4.5$ & $<5.0$ & high U, Zr \\
III & Calcareous sediment & $1.3-5.2$ & $4.5-17$ & $<4.2$ & low U, Zr \\
IV & Limestone & $2.0-3.7$ & $>17$ & $<1.7$ & low U, Zr \\
\hline
\end{tabular}

The groups II and III have been subdivided in order to investigate any regional or stratigraphical changes in the lithogeochemistry. Information on the predominant lithostratigraphy of a sampled drainage area was noted by the samplers. Table 9 lists the groups and subgroups and Table 10 their typical chemical composition as expressed by the geometric mean for each of the 17 elements. The standard deviation of the geometric mean is normally less than 15 per cent. $\mathrm{Ni}$ and Mo analyses are omitted from Table 10 as their concentrations are generally below the detection limit.

The chemical variation between, and within, the main groups is illustrated by fig. 58 . Fig. 59 shows a division of the survey area based on the chemical grouping of the stream silt samples. In the following description of each of the main lithological groups it should be 

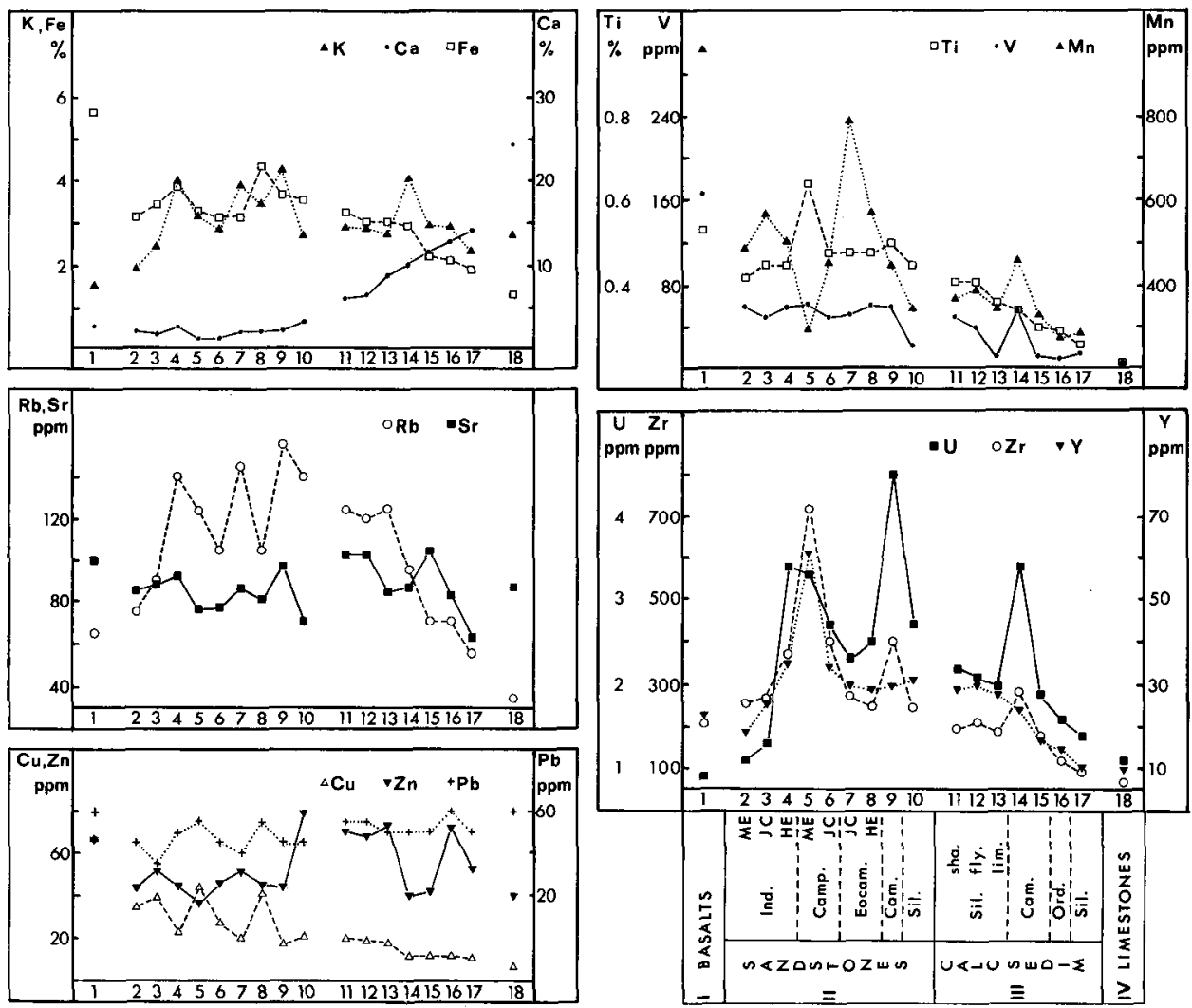

Fig. 58. Chemical variation in the $<75 \mu \mathrm{m}$ grain size fraction of stream silt samples from the Peary Land region, North Greenland. The geometrical means of the analyses of samples from each subgroup are plotted for 14 of the 18 analysed elements. Subgroups are defined in Table 9. For analytical values, method of analysis and abbreviations, see Table 10 .

borne in mind that owing to the irregular sampling density the sampling may not be representative of entire lithostratigraphical units.

Basic volcanic rocks (group I), are, as expected, easy to distinguish chemically from the sedimentary rocks, especially by the high content of $\mathrm{Cr}, \mathrm{Mn}$, and $\mathrm{Fe}$ (see Table 10 and fig. 58). The extent of the basalts of the Zig-Zag Dal Formation on Mylius-Erichsen Land and $J$. C. Christensen Land (Jepsen et al., this report) is clearly outlined by the stream silt samples of this group (fig. 59); centrally in J. C. Christensen Land the basalts are characterised by increased content of $\mathrm{Cu}, 98-114 \mathrm{ppm}$, as compared with the mean of $67 \mathrm{ppm} \mathrm{Cu}$.

Two samples from Mylius-Erichsen Land contain c. $100 \mathrm{ppm} \mathrm{Ni}$, otherwise the Ni content of the basalts is below, or near, the detection limit. One sample from the northern edge of the basalt area of Mylius-Erichsen Land containing 4.12\% K, $6.6 \mathrm{ppm} \mathrm{U,} 1510 \mathrm{ppm} \mathrm{Zr,} 140$ ppm Y, and $210 \mathrm{ppm} \mathrm{Mo,} \mathrm{is} \mathrm{thought} \mathrm{to} \mathrm{be} \mathrm{derived} \mathrm{from} \mathrm{an} \mathrm{acid} \mathrm{volcanic} \mathrm{rock.}$ 
Table 9. Geochemical and lithostratigraphical grouping of the $<75 \mu \mathrm{m}$ grain size fraction of stream silt samples from the Peary Land region, North Greenland

\begin{tabular}{lrl}
\hline Lithogeochemical groups & & Lithostratigraphical subgroups \\
\hline Basic volcanic rocks & 1 & Zig-Zag Dal Basalt Formation; dolerite \\
\hline & 2 & Independence Fjord Group, Mylius-Erichsen Land \\
& 3 & Independence Fjord Group, J. C. Christensen Land \\
& 4 & Independence Fjord Group, Heilprin Land \\
& 6 & Campanuladal Formation, Mylius-Erichsen Land \\
II Sandstones & 7 & Upper Campanuladal Formation, J. C. Christensen Land \\
& 8 & Morænesø Formation; Fyns Sø Formation, Heilprin Land \\
& 9 & Portfjeld Formation; Buen Formation \\
& 10 & Silurian flysch units \\
\hline & 11 & Silurian shale formations \\
& 12 & Silurian flysch units \\
III Calcareous sediments/ & 13 & Silurian limestone formations \\
dolomitic sediments & 14 & Portfjeld Formation \\
& 15 & Brønlund Fjord Group; Tavsens Iskappe Group \\
& 16 & Wandel Valley Formation; Børglum River Formation \\
\hline IV Limestones & 17 & Silurian dolomite formations \\
\hline
\end{tabular}

For stratigraphical position of the formations see Henriksen (this report).

Several samples from Heilprin Land (fig. 59) show typical basalt composition reflecting the occurrence of dolerite dykes in that area.

Sandstones (group II). The samples with sandstone geochemistry are divided into several groups. These show considerable chemical variation illustrating the changes in the depositional environment during space and time. The Proterozoic sandstone sequences (subgroups $2,3,4)$ - the Independence Fjord Group (Collinson, this report) - display an increase in $\mathbf{K}$, $\mathrm{Fe}, \mathrm{U}, \mathrm{Rb}$, and $\mathrm{Zr}$ from Mylius-Erichsen Land westwards via J. C. Christensen Land to Heilprin Land, indicating a stronger influence of granitic source rocks in Heilprin Land. The varying chemistry of the sandstones is in accordance with the facies changes described by Collinson (1979).

When the Proterozoic sandstone formations (below the basalts) in Mylius-Erichsen Land and J. C. Christensen Land (subgroups 2 and 3) are compared with the younger sandstone (subgroups 5 and 6) belonging to the Campanuladal Formation (Clemmensen, 1979) above the basalts, an increase in $\mathrm{K}, \mathrm{Ti}, \mathrm{Ga}, \mathrm{Pb}, \mathrm{U}, \mathrm{Rb}, \mathrm{Y}, \mathrm{Zr}$, and $\mathrm{Nb}$ is noted in samples from the younger units, which again could reflect a change towards more granitic source rocks upwards. Apart from this general feature basaltic material is observed in some of the samples from the younger sandstone formations.

In Heilprin Land, the influence of granitic source rocks seems to have weakened during the deposition of the Eocambrian Morænesø Formation, i.e. decrease in $\mathrm{K}, \mathrm{Rb}, \mathrm{U}, \mathrm{Zr}$ in samples from the Proterozoic sandstones (subgroup 4) to the Morænesø Formation deposits (subgroup 8). Later, when the Cambrian Portfjeld and Buen Formations (subgroup 9) were 
Table 10. Chemical composition of the $<75 \mu \mathrm{m}$ grain size fraction of stream silt samples from the Peary Land region, North Greenland

\begin{tabular}{|c|c|c|c|c|c|c|c|c|c|c|c|c|c|c|c|c|c|c|c|c|c|c|}
\hline \multicolumn{2}{|r|}{ Main Group } & \multicolumn{2}{|c|}{ Subgp. } & \multicolumn{2}{|l|}{ no. } & $\begin{array}{l}K \\
\%\end{array}$ & $\begin{array}{l}\mathrm{Ca} \\
\%\end{array}$ & \multirow{2}{*}{$\begin{array}{c}\frac{\pi}{\%} \\
0.53\end{array}$} & \multirow{2}{*}{$\begin{array}{c}\begin{array}{c}V \\
\text { ppm }\end{array} \\
164\end{array}$} & \multirow{2}{*}{$\begin{array}{c}\begin{array}{c}\mathrm{Cr} \\
\mathrm{ppm}\end{array} \\
268\end{array}$} & \multirow{2}{*}{$\begin{array}{c}\begin{array}{c}\mathrm{Mn} \\
\mathrm{ppm}\end{array} \\
\mathbf{9 6 5}\end{array}$} & \multirow{2}{*}{$\begin{array}{c}\mathrm{Fe} \\
\% \\
5.59\end{array}$} & \multirow{2}{*}{$\begin{array}{c}\begin{array}{c}\mathrm{Cu} \\
\mathrm{ppm}\end{array} \\
67\end{array}$} & \multirow{2}{*}{$\begin{array}{c}\begin{array}{c}\mathrm{Zn} \\
\mathrm{ppm}\end{array} \\
68\end{array}$} & \multirow{2}{*}{$\frac{\begin{array}{r}\mathrm{Ga} \\
\mathrm{ppm}\end{array}}{8}$} & \multirow{2}{*}{$\frac{\begin{array}{c}\text { Sr } \\
\text { ppm }\end{array}}{98}$} & \multirow{2}{*}{$\begin{array}{r}\begin{array}{c}\mathrm{Pb} \\
\mathrm{ppm}\end{array} \\
60\end{array}$} & \multirow{2}{*}{$\frac{\begin{array}{c}U \\
\mathrm{ppm}\end{array}}{0.9}$} & \multirow{2}{*}{$\begin{array}{c}\begin{array}{c}\mathrm{Rb} \\
\mathrm{ppm}\end{array} \\
65\end{array}$} & \multirow{2}{*}{$\frac{\begin{array}{c}Y \\
p p m\end{array}}{25}$} & \multirow{2}{*}{$\begin{array}{c}\begin{array}{c}\mathrm{Zr} \\
\mathrm{ppm}\end{array} \\
210\end{array}$} & \multirow{2}{*}{$\begin{array}{r}\begin{array}{c}\mathrm{Nb} \\
\mathrm{ppm}\end{array} \\
\frac{10}{10}\end{array}$} \\
\hline I & Basalts & & & 1 & 29 & 1.51 & 2.60 & & & & & & & & & & & & & & & \\
\hline \multirow{4}{*}{11} & \multirow{4}{*}{ Sandstones } & Ind. & $\begin{array}{l}\mathrm{ME} \\
\mathrm{JC} \\
\mathrm{HE}\end{array}$ & $\begin{array}{l}2 \\
3 \\
4\end{array}$ & $\begin{array}{r}11 \\
5 \\
10\end{array}$ & $\begin{array}{l}1.88 \\
2.46 \\
3.96\end{array}$ & $\begin{array}{l}1.82 \\
1.58 \\
2.36\end{array}$ & $\begin{array}{l}0.42 \\
0.45 \\
0.45\end{array}$ & $\begin{array}{l}60 \\
48 \\
60\end{array}$ & $\begin{array}{l}0 \\
0 \\
0\end{array}$ & $\begin{array}{l}486 \\
559 \\
506\end{array}$ & $\begin{array}{l}3.10 \\
3.37 \\
3.85\end{array}$ & $\begin{array}{l}35 \\
39 \\
23\end{array}$ & $\begin{array}{l}44 \\
52 \\
45\end{array}$ & 7 & $\begin{array}{l}85 \\
88 \\
92\end{array}$ & $\begin{array}{l}45 \\
35 \\
50\end{array}$ & 3.4 & $\begin{array}{r}75 \\
90 \\
140\end{array}$ & $\begin{array}{l}25 \\
35\end{array}$ & $\begin{array}{l}250 \\
270 \\
370\end{array}$ & $\begin{array}{l}10 \\
20\end{array}$ \\
\hline & & Camp. & $\begin{array}{l}M E \\
J C\end{array}$ & $\begin{array}{l}5 \\
6\end{array}$ & $\begin{array}{l}4 \\
9\end{array}$ & $\begin{array}{l}2.89 \\
2.82\end{array}$ & & & $\begin{array}{l}63 \\
50\end{array}$ & $\begin{array}{l}0 \\
0\end{array}$ & & & $\begin{array}{l}44 \\
27\end{array}$ & & 1 & $\begin{array}{l}76 \\
77\end{array}$ & $\begin{array}{l}55 \\
45\end{array}$ & $\begin{array}{l}2.8 \\
2.7\end{array}$ & $\begin{array}{l}125 \\
115\end{array}$ & & & $\begin{array}{l}20 \\
20\end{array}$ \\
\hline & & Eocam & $\begin{array}{c}J C \\
\text { T. } H E\end{array}$ & $\begin{array}{l}7 \\
8\end{array}$ & $\begin{array}{l}4 \\
6\end{array}$ & $\begin{array}{l}3.86 \\
3.43\end{array}$ & $\begin{array}{l}1.75 \\
1.88\end{array}$ & $\begin{array}{l}0.48 \\
0.48\end{array}$ & $\begin{array}{l}56 \\
59\end{array}$ & $\begin{array}{r}77 \\
172\end{array}$ & $\begin{array}{l}793 \\
578\end{array}$ & & $\begin{array}{l}20 \\
41\end{array}$ & $\begin{array}{l}52 \\
46\end{array}$ & $\begin{array}{r}11 \\
8\end{array}$ & $\begin{array}{l}86 \\
81\end{array}$ & $\begin{array}{l}40 \\
55\end{array}$ & $\begin{array}{l}2.3 \\
2.5\end{array}$ & $\begin{array}{l}145 \\
115\end{array}$ & & & $\begin{array}{l}20 \\
20\end{array}$ \\
\hline & & $\begin{array}{l}\text { Cam. } \\
\text { Sil. }\end{array}$ & & $\begin{array}{r}9 \\
10\end{array}$ & $\begin{array}{l}19 \\
10\end{array}$ & $\begin{array}{l}4.27 \\
2.71\end{array}$ & $\begin{array}{l}1.95 \\
3.18\end{array}$ & $\begin{array}{l}0.47 \\
0.45\end{array}$ & $\begin{array}{l}56 \\
32\end{array}$ & $\begin{array}{r}24 \\
0\end{array}$ & $\begin{array}{l}455 \\
347\end{array}$ & $\begin{array}{l}3.61 \\
3.48\end{array}$ & $\begin{array}{l}17 \\
21\end{array}$ & $\begin{array}{l}44 \\
79\end{array}$ & $\begin{array}{r}10 \\
9\end{array}$ & $\begin{array}{l}97 \\
69\end{array}$ & $\begin{array}{l}45 \\
45\end{array}$ & $\begin{array}{l}4.5 \\
2.7\end{array}$ & $\begin{array}{l}155 \\
140\end{array}$ & $\begin{array}{l}40 \\
30\end{array}$ & $\begin{array}{l}400 \\
250\end{array}$ & $\begin{array}{l}20 \\
20\end{array}$ \\
\hline \multirow{2}{*}{ III } & \multirow{2}{*}{$\begin{array}{l}\text { Calcareous } \\
\text { dolomitic } \\
\text { sediments }\end{array}$} & Sil. & $\begin{array}{l}\text { sha. } \\
\text { fly. } \\
\text { lim. }\end{array}$ & $\begin{array}{l}11 \\
12 \\
13\end{array}$ & $\begin{array}{l}18 \\
34 \\
25\end{array}$ & $\begin{array}{l}2.86 \\
2.84 \\
2.75\end{array}$ & $\begin{array}{l}6.06 \\
6.43 \\
7.73\end{array}$ & $\begin{array}{l}0.41 \\
0.41 \\
0.36\end{array}$ & $\begin{array}{l}50 \\
39 \\
13\end{array}$ & $\begin{array}{l}0 \\
0 \\
0\end{array}$ & $\begin{array}{l}375 \\
387 \\
345\end{array}$ & & $\begin{array}{l}20 \\
19 \\
18\end{array}$ & $\begin{array}{l}71 \\
69 \\
73\end{array}$ & $\begin{array}{r}11 \\
9 \\
4\end{array}$ & $\begin{array}{r}108 \\
107 \\
83\end{array}$ & $\begin{array}{l}55 \\
55 \\
50\end{array}$ & $\begin{array}{l}2.2 \\
2.1 \\
2.0\end{array}$ & $\begin{array}{l}125 \\
120 \\
125\end{array}$ & $\begin{array}{l}30 \\
30 \\
30\end{array}$ & $\begin{array}{l}200 \\
210 \\
190\end{array}$ & $\begin{array}{l}20 \\
20 \\
20\end{array}$ \\
\hline & & $\begin{array}{l}\text { Cam. } \\
\text { Ord. } \\
\text { Sil. }\end{array}$ & & $\begin{array}{l}14 \\
15 \\
16 \\
17\end{array}$ & $\begin{array}{r}14 \\
19 \\
20 \\
5\end{array}$ & $\begin{array}{l}3.99 \\
2.89 \\
2.87 \\
2.33\end{array}$ & $\begin{array}{r}9.99 \\
11.60 \\
12.72 \\
13.85\end{array}$ & $\begin{array}{l}0.34 \\
0.30 \\
0.29 \\
0.26\end{array}$ & $\begin{array}{l}47 \\
13 \\
11 \\
16\end{array}$ & $\begin{array}{l}0 \\
0 \\
0 \\
0\end{array}$ & $\begin{array}{l}460 \\
327 \\
277 \\
284\end{array}$ & $\begin{array}{l}2.86 \\
2.21 \\
2.10 \\
1.87\end{array}$ & $\begin{array}{l}12 \\
12 \\
12 \\
11\end{array}$ & $\begin{array}{l}40 \\
42 \\
72 \\
53\end{array}$ & $\begin{array}{l}2 \\
0 \\
0 \\
0\end{array}$ & $\begin{array}{r}86 \\
104 \\
82 \\
62\end{array}$ & $\begin{array}{l}50 \\
50 \\
60 \\
50\end{array}$ & $\begin{array}{l}3.4 \\
1.9 \\
1.6 \\
1.4\end{array}$ & $\begin{array}{l}95 \\
70 \\
70 \\
55\end{array}$ & $\begin{array}{l}25 \\
15 \\
15 \\
10\end{array}$ & $\begin{array}{l}290 \\
180 \\
120 \\
100\end{array}$ & $\begin{array}{l}10 \\
10 \\
10 \\
10\end{array}$ \\
\hline 10 & Liminsturies & & & 18 & 35 & 2.64 & 24.33 & 0.20 & $\mathbf{v}$ & 0 & 216 & 1.33 & $\boldsymbol{F}$ & 40 & $\mathbf{v}$ & $\mathbf{0 0}$ & 00 & 1.1 & $3 b$ & 10 & 10 & 10 \\
\hline
\end{tabular}

The figures represent the geometrical mean of the analyses for each group.

N: number of samples. Ind.: Independence Fjord Group. Camp.: Campanuladal Formation. Eocam.: Eocambrian. Cam.: Cambrian. Ord.: Ordovician. Sil.: Silurian. sha.: shale. fly.: flysch. lim.: limestone. ME: Mylius-Erichsen Land. JC: J.C. Christensen Land.

HE: Heilprin Land.

Samples are analysed at Risø National Laboratory by delayed neutron counting for $U$ and radioisotope energy dispersive $X$-ray fluorescence for the other elements.

formed in this region, proximity to source rocks of granitic composition is again indicated by the sandy units of these formations (high $\mathrm{K}, \mathrm{U}, \mathrm{Rb}, \mathrm{Y}, \mathrm{Zr}$ ).

The variation in the trace element content of the sandstone subgroups is not correlated with changes in major elements, hence it cannot be explained by simple changes in the main mineralogical composition. More information is needed to discuss the pattern further.

Sedimentary deposits of the Lower Palaeozoic platform (groups III and IV) are typically calcareous. The subgroups have been arranged in fig. 58 with increasing Ca content towards the right of the diagrams. All limestones (group IV) of Lower Palaeozoic age are very similar in chemistry and are clearly distinguishable from the calcareous/dolomitic sediments by the high $\mathrm{Ca}$ content and low content of most other elements.

The typical feature for the samples from calcareous sediments (subgroups 10-17) is a negative correlation of $\mathrm{Ca}$ with most other elements except $\mathrm{K}, \mathrm{Sr}, \mathrm{Zn}$, and $\mathrm{Pb}$. The samples from the Silurian lithostratigraphical units flysch, shale, and limestone respectively (subgroups 11, 12,13) show little chemical variation indicating a uniform depositional environment. A small group (subgroup 10) with sandstone composition occurs in the lower part of the Silurian flysch zone in central Peary Land (fig. 59). These rocks are characterised by high $\mathrm{Fe}, \mathrm{U}, \mathrm{Rb}, \mathrm{Zr}$, (Ti) and low $\mathrm{Ca}, \mathrm{Sr}, \mathrm{Pb}$ relative to the other Silurian deposits. The chemistry thus demonstrates a local change in the lithofacies of the flysch units.

Among the dolomitic sediments of Lower Palaeozoic age (subgroups 14-17) the Portfjeld 


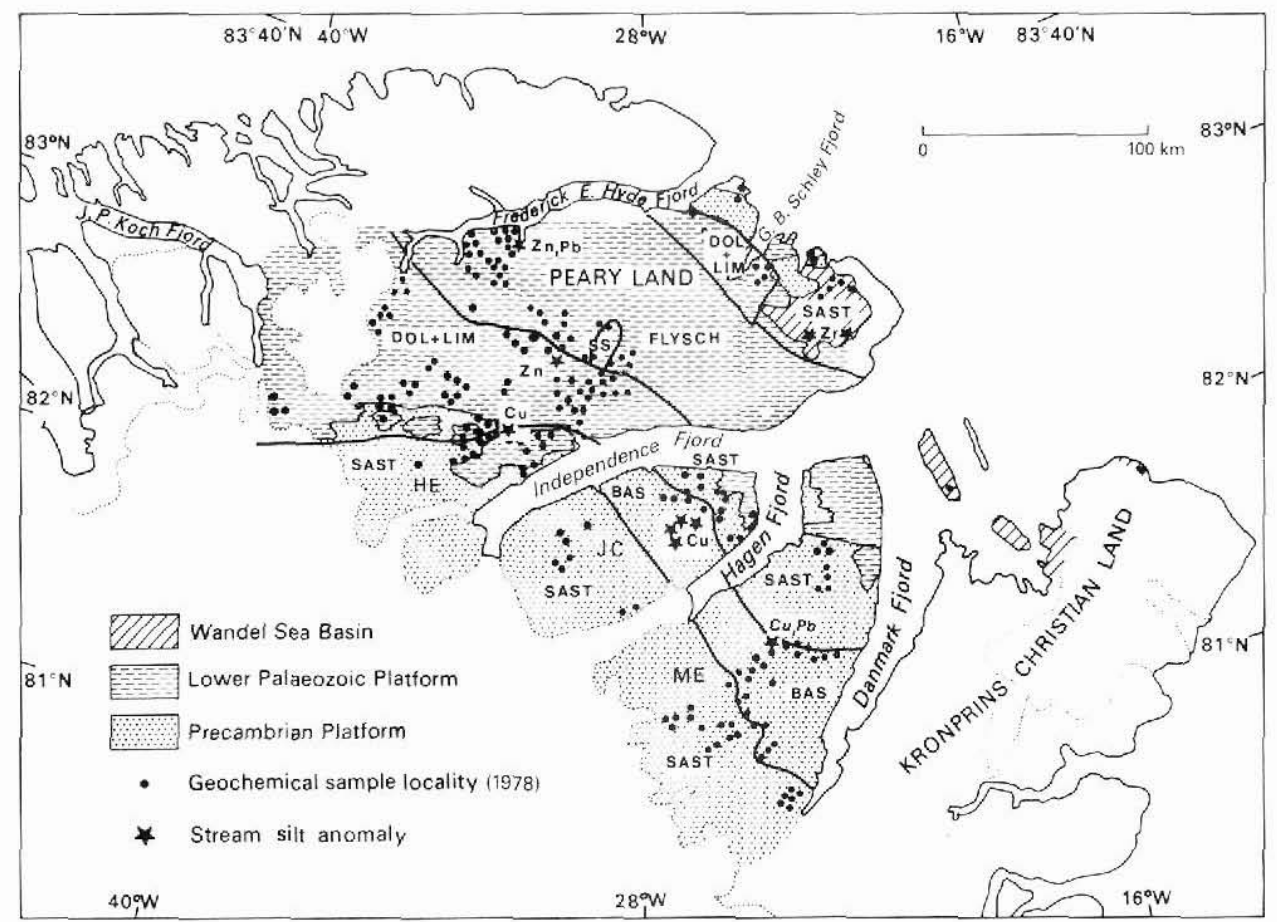

Fig. 59. Lithogeochemical subdivision of the survey area based on the chemistry of stream silt samples and location of stream silt anomalies. Lithogeochemical units refer to Table 9. HE: Heilprin Land. JC: J. C. Christensen Land. ME: Mylius-Erichsen Land. BAS: basalts (group I). SAST and SS: sandstones (group II). DOL+LIM: dolomitic sediments and limestone (groups III and IV). FLYSCH comprises the subgroups $11-13$ of group III.

Formation (subgroup 14) stands out with deviating chemistry characterised by high $\mathrm{K}, \mathrm{V}$, $\mathrm{Zr}, \mathrm{U}$ and high $\mathrm{K} / \mathrm{Rb}$ ratio. The calcareous units of this formation thus resemble the sandy units (subgroup 9). The sedimentary environment for the Portfjeld Formation is described as a shallow water, near shore environment (O'Connor, 1979).

Deposits from the Upper Palaeozoic-Tertiary Wandel Sea Basin are not represented in Table 9 and fig. 59 because stream silt samples were collected from only two sites in that area. However, some soil samples were collected and 16 of these have been sieved and analysed in the same way as the silt samples. The range of metal contents of the soils compares with the range in the silts. All samples from the Wandel Sea Basin have sandstone chemistry, i.e. belong to group I. Two samples from near G. B. Schley Fjord, fig. 59, show addition of basic material, $\mathrm{Cr}, \mathrm{Fe}, \mathrm{Mn}$, and Ni. Seven samples from the Upper Jurassic - Lower Cretaceous Ladegårdsåen Formation (Håkansson, 1979) are characterised by a very high $\mathrm{Zr}$ content. 
Table 11. High element values encountered in stream silt (-75 $\mu \mathrm{m}$ fraction)

\begin{tabular}{lllll}
\hline Element & No. & Concentrations & Lithostratigraphy & Location \\
\hline $\mathrm{Cr}$ & 1 & $1434 \mathrm{ppm}$ & Proterozoic sandstone & Heilprin Land \\
$\mathrm{Cu}$ & 5 & $103-144 \mathrm{ppm}$ & Proterozoic basalt & J. C. Christensen Ld \\
& 1 & $113 \mathrm{ppm}$ & Holerite in Prot. sdst & Heilprin Land \\
$\mathrm{Zn}$ & 1 & $92 \mathrm{ppm}$ & Portfjeld Formation & South Peary Land \\
& 5 & $105-232 \mathrm{ppm}$ & Ordovician dolomite & South Peary Land \\
& 2 & $93,107 \mathrm{ppm}$ & Ordovician limestone & South Peary Land \\
& 1 & $316 \mathrm{ppm}$ & Silurian flysch & Peary Land \\
& & & & Frederick E. Hyde Fj. \\
& 1 & $121 \mathrm{ppm}$ & Cambrian dolomite & South Peary Land \\
& 1 & $109 \mathrm{ppm}$ & Ordovician dolomite & South Peary Land \\
& & $110-125 \mathrm{ppm}$ & Wandel Sea Basin & East Peary Land \\
$\mathrm{Pb}$ & 1 & $90 \mathrm{ppm}$ & Portfjeld Formation & South Peary Land \\
& 2 & $90,110 \mathrm{ppm}$ & Ordovician limestone & South Peary Land \\
& 2 & $90,110 \mathrm{ppm}$ & Silurian flysch & Frederick E. Hyde Fjord \\
$\mathrm{U}$ & 2 & $6.2,7.0 \mathrm{ppm}$ & Proterozoic sandstone & Heilprin Land \\
& 2 & $6.7,7.1 \mathrm{ppm}$ & Wandel Sea Basin & East Peary Land \\
$\mathrm{Zr}$ & 5 & $1310-3410 \mathrm{ppm}$ & Wandel Sea Basin & East Peary Land \\
\hline
\end{tabular}

\section{Indication of mineralisation}

Table 10 and fig. 58 provide information on typical values for the concentration of elements in different lithostratigraphical units. For the evaluation of potential mineralisations the anomalously high values have been listed in Table 11.

A reconnaissance study of stream sediment samples in Washington Land (Steenfelt, 1978) showed that the concentration of base metals and uranium generally increased with decreasing grain size fraction. In the present drainage survey samples were sieved into two grain size fractions $<75 \mu \mathrm{m}$ and $75-250 \mu \mathrm{m}$. Both fractions were analysed. The results show a pronounced tendency for enhanced concentrations of the metals $\mathrm{Ti}, \mathrm{Cr}, \mathrm{Fe}, \mathrm{Cu}, \mathrm{Zr}, \mathrm{Y}$ in the finest fraction. A less pronounced tendency exists for $\mathrm{V}, \mathrm{Mn}, \mathrm{Zn}, \mathrm{Ga}, \mathrm{Pb}, \mathrm{Sr}, \mathrm{Rb}$ whereas $\mathrm{K}$ and $\mathrm{Ca}$ concentrations do not vary with grain size. The enhancement factor for the finer fraction relative to the coarser fraction for the first group of elements is typically 1.5. High values quoted in the following are from the analysis of the $<75 \mu \mathrm{m}$ grain size fraction.

Very few significant anomalies have been found, but some high values listed in Table 11 are interesting as they may indicate the presence of mineralisation. The most significant anomalies are plotted on fig. 59.

The pattern of high values compares, to a certain extent, with the result of a heavy mineral study of sand samples forming the other part of the reconnaissance drainage sampling programme (Ghisler \& Stendal, this report). The Cu-bearing basalts in J. C. Christensen Land (Ghisler \& Stendal, Table 6) are outlined by both sample media, but the stream silt does not indicate increased $\mathrm{Cu}$ content in all places where chalcopyrite is found. Some of the high $\mathrm{Pb}$ values of the stream silt coincide with the occurrence of galena in the heavy mineral concentrates. One significant $\mathrm{Zn}-\mathrm{Pb}$ anomaly in the stream silt, occurring in the Silurian flysch south of Frederick E. Hyde Fjord, confirms the sulphide mineralisation mentioned by Ghisler \& Stendal (this report). Sphalerite has not been noted in places where high $\mathbf{Z n}$ values of stream silt are found. 


\section{References}

Clemmensen, L. B. 1979: Notes on the palaeogeographical setting of the Eocambrian tillite-bearing sequence of southern Peary Land, North Greenland. Rapp. Grønlands geol. Unders. 88, 15-22.

Collinson, J. D. 1979: The Proterozoic sandstones between Heilprin Land and Mylius-Erichsen Land, eastern North Greenland. Rapp. Grønlands geol. Unders. 88, 5-10.

Ghisler, M., Henriksen, N., Steenfelt, A. \& Stendal, H. 1979: A regional reconnaissance, geochemical survey in the Proterozoic-Phanerozoic platform succession of the Peary Land region, North Greenland. Rapp. Grønlands geol. Unders. 88, 85-91.

Håkansson, E. 1979: Carboniferous to Tertiary development of the Wandel Sea Basin, eastern North Greenland. Rapp. Grønlands geol. Unders. 88, 73-84.

O'Connor, B. 1979: The Portfjeld Formation (?early Cambrian) of eastern North Greenland. Rapp. Grønlands geol. Unders. 88, 23-28.

Steenfelt, A. 1978: Reconnaissance drainage sampling for geochemical exploration, Washington Land 1976. GGU internal report.

Steenfelt, A. \& Kunzendorf H. 1979: Geochemical methods in uranium exploration in northern East Greenland. In Watterson. J. R. \& Theobald, P. K. (edit.) Geochemical Exploration 1978. Proceedings 7th Int. Symp. Exploration Geochemistry, April 1978, 429-442. 